\title{
NEWS OF FELLOWS AND SCHOLARS
}

\author{
PH. D.'S RECEIVED
}

The American University

VAL MoghadaM - Accumulation Strategy and Class Formation: The Making of the Industrial Labor Force in Iran, 1962-77.

Columbia University

Judith Marie Barsalou - Foreign Labor in Sa'udi Arabia: The Creation of a Plural Society.

LAURIE A. BRAND - Building the Bridge of Return: Palestinian Corporate Mobilization in Egypt, Kuwait, and Jordan.

Muhammad Y. MUSLIH - Urban Notables, Ottomanism, Arabism, and the Rise of Palestinian Nationalism 1864-1920.

KHALIL I. SHIKAKI - Nuclear Deterrence in the Arab-Israeli Conflict.

AnNabelle Sreberny-Mohammadi - The Power of Non-Mass Communication: The Case of Iran.

Harvard University

KAREN Pliskin - The Dynamics of Semiotics: The Study of Silver Engravers and Their Art in Shiraz, Iran.

LAURIE MYLROIE - Saudi Relations with the Smaller Gulf States.

MOHAMMED AL-SABAH - General Equilibrium Analysis of Government Expenditures in an Oil Exporting Country: The Case of Kuwait.

Indiana University

RONALD G. WOLFE - Ibn Madā' al-Qurțubī and the Book in Refutation of the Grammarians: A Medieval Criticism of Arabic Rationalist Grammar.

New York University

KARL SCHAEFER - Jerusalem under the Ayyubids and Mamluks.

Princeton University

VICTORIA ROWE HOLBROOK - The Ultimate Romance: Galeb's Beauty and Love.

EWEN MaCMILlan - Priorities underlying the Evolution of an Arabic Short Vowel System.

University of Arizona

'ABD AL-RAHMAN KURDI - The Islamic State, a Perspective of the Islamic Holy Revelation.

University of California, Los Angeles

AbDullah Al-Askar - Regional Politics, A Case Study: Al-Yamama in the 6th and 7th Centuries.

KenNeTH CunO - Landholding, Society and Economy in Rural Egypt, 17401850: A Case Study of al-Daqahliyya Province. 
University of Chicago

DANiEl GoffMAN - Izmir as a Commercial Center: The Impact of Western Trade on an Ottoman Port, 1570-1650.

Russell G. KeMPINERS - The Struggle for Khurasan: Aspects of Political, Military, and Socio-Economic Interaction in the Early 8th/14th Century.

NoRTON RICHARD - Harakat Amal and the Political Mobility of the Shi'a of Lebanon.

University of Michigan

Ani ABDElJabBar ABDELJABER - Evaluation of Ibn Madā's Criticism of Arab Grammarians.

Abdul Hamid Ali Abumdas - Libyan Arabic Phonology.

Rashid Abdulrahman Addeweesh - A Syntactic and Semantic Study of hāl "Circumstantial" Structures in Modern Literary Arabic Prose Literature.

Mukhtar Abugaila Ageil - Naval Policy and the Rise of the Fleet of Ifrīqiyyah from the 1st to 3rd Centuries A.H. (7th to 9th Centuries A.D.).

Mahmoud Mohammed Adel AL-BATAL - Sociostylistic Stratification of Arabic in Makkah.

William JAMES HABLIN - The Fātimid Army during the Early Crusades.

MUHAMMAD FARIS JAMIL - Islamic Wiraqah "Stationery" during the Early Middle Ages.

Nidhal Shaban Mostafa - Cognitive Development, Spatial Ability and Achievement in Science among Saudi Arabian Students.

Mohammed Ahmed SAlEm - Motivation of National and Expatriate Construction Workers in Jordan.

ANTAR IBN-STANFORD SMITH - Significant Features of al-Jașșāṣ' Methodology for Deriving Legal Rulings from the Qur'ān.

TERRY LYNN TODD - A Grammar of Dimili (Also known as Zaza).

University of Utah

Hussein El-KhAfAifi - The Role of the Cairo Language Academy in Coining Arabic Scientific Terminology: An Historical and Linguistic Evaluation.

\section{PH. D.'s IN PROGRESS}

The Hebrew University

ESTHER WARKOV - Instrumental Improvisation in Urban Iraqi Music as Performed by Jewish Musicians in Iraq and Israel.

Princeton University

KEITH LEWINSTEIN - Islamic Sectarianism in Buyyid Iraq and Iran.

KaTHLEEN REHN - The Administrations of Shah Ismai'il and the Betrayal of the Qizilbash Cause.

University of Arizona

WALTER BEVENS - Geography of the Yemen Records in the Works of PreModern Geographers and Travelers.

NeYSA SAUNDERS - Al-Jahiz' Book of Misers: Translation and Critical Study.

University of California, Los Angeles

Muhammad FreiH - The Egyptian Campaign and the Failure of Wahhabism among the Hijaz Bedouins.

AbDulla Mutawa - The Role of the Ulama in the First Saudi State. 
University of Chicago

Keith Weissman - Baghdad under the Mongols.

University of Utah

SAlem AJluni - Israel and the West Bank: A Post-1967 Economic History.

NACKLIE BOU-NAKLIE - The Local Auxiliary Forces in the Period of the French Mandate in Syria and Lebanon and in the First Years of Independence, 1918 1948.

Etaher Elguradi - A Comparative Study of the Religious Ideas of Abu al-'Ala' al-Ma'arri and Umar al-Khayyam.

Shireen M. Khazani - The Nineteenth Century Persian Merchant.

FRANCINE MAHAK - A Translation and Critical Analysis of Winter Sleep, a Modern Persian Novel by Goli Taraqqi.

ERNEST RANDA - Ahmad b. Tulun and the Disillusion of the Abbasid Caliphate.

\section{ApPointments and Promotions}

Naji Abdeljabbar Abdeljaber - Assistant Professor, Birzeit University.

IBRAhIm ABU-Lughod - Chairman, Dept. of Political Science, Northwestern University.

AbDul Hamid Ali Abumdas - Professor of Arabic Linguistics, Libyan U.

AlPARSLAN AÇIKGENÇ - Visiting Scholar, University of Chicago.

RASHID ABDULRAHMAN ADDEWEESH - Arabic Language Institute, King Saud University, Riyadh.

RIAD AJAMI - Visiting Professor of Management, Wharton School (fall 1985).

LeOnardo Alishan - Associate Professor, University of Utah.

Michael W. Allen - Chief of Order Division, Library of Congress.

Roger Allen - Professor, Oriental Studies, University of Pennsylvania.

GaLAL AmIN - Visiting Faculty, Economics, UCLA.

A. Tosun Aricanli - Assistant Professor of Economics, CMES, Harvard U.

Ahmad Ashraf - Lecturer of Sociology of M.E., Princeton University.

ABDULLAH AL-ASKAR - Lecturer, University of Riyadh.

DON BABAI - Assistant Professor of Government, CMES, Harvard University.

NitZA BeN-DOV - Lecturer in Hebrew, Princeton University.

HenRy BIEnEN - James S. McDonnell Distinguished University Professor, Princeton University.

RAmzı BIKhAZI - Curator of Islamic Coins, Dar al-Athar al-Islamiyya, Kuwait National Museum.

LEONARD BINDER - Professor of Political Science, UCLA.

ROBERT BURROWES - Visiting Scholar, Kevorkian Center, NYU.

Charles Butterworth - Professor, Government and Politics, University of Maryland.

JOHN CARSWELL - Director, The David and Alfred Smart Gallery, and Research Associate (Professor), the Oriental Institute, University of Chicago.

KenNeth CUNO - Visiting Assistant Professor of History, AUC.

JOHN DAMIS - Visiting Professor of Government, CMES, Harvard University.

Martha Dukas - Deputy Director for Technical Services, Sultan Qaboos University Library, Oman.

Mushira EID - Dept. of Languages, Arabic, University of Utah.

E. Christian Filstrup - Assistant Chief, Overseas Operations Division, Library of Congress. 
Daniel Goffman - Assistant Professor, History, Ball State University.

YeShAYUHU GoldFELD - Visiting Fellow, Princeton University.

YVONNE HADDAD - Professor, Islamic Studies, Hartford Seminary.

SylviA G. HAIM - Visiting, Near Eastern and Judaic Studies, Brandeis U.

ViCTORIA HOLBROOK - Mellow Fellow and Lecturer, Columbia University.

ARthur HertzBerg - Senior Research Scholar, Columbia University.

YUSUF IBISH - Chair in Islamic Studies, AUC.

MAHMOOD IBRAHIM - Assistant Professor of History, Bir Zeit University.

Charles Issawi - Acting Director, Near East Studies Program, PrincetonNYU.

NASIR MOHAMmed AL-JEHANI - Linguistics Dept., University of Mecca.

MOHA MMED JIYAD - Assistant Professor, University of Massachusetts, Amherst.

CEMAL KAFADAR - Instructor of Turkish, Princeton University.

EliE KEDOURIE - Visiting Faculty, Near Eastern and Judaic Studies, Brandeis

University.

HUSSEIN M. El-KhAFAIFI - Lecturer in Arabic, University of Pennsylvania.

Samir Khalaf - Visiting Professor, Sociology of Middle East, Princeton U.

RASHid KHALIDI - Assistant Professor of Political Science, Columbia University.

PhILIP KHOURY - Associate Professor, History, MIT.

DAVID KING - Chair in History of Science, Johann Wolfgang Goethe University,

Frankfurt.

William KRItzBerg - Assistant Foreign Editor for the Middle East, The New York Times.

R. KEVIN LACEY - Visiting Lecturer on Arabic, CMES, Harvard University.

HABIB LADJEVARDI - Director, Iranian Oral History Project, CMES, Harvard University.

Abraham LAVI - Visiting Scholar, Arabic studies, CMES, Harvard University. Michel LeGall - Assistant Professor, History, St. Olaf College.

FUSUN LEVENTOGLU - Lecturer in Turkish (1985-86), University of Chicago.

EWEN MACMILLAN - Lecturer in Arabic, University of Minnesota.

WILFERD MADELUNG - Visiting Scholar, University of Chicago.

JON MANDAVILLE - Director, American Institute for Yemeni Studies.

ŞERIF MARDIN - Visiting Professor of History and Sociology, Columbia University (spring).

SHAUN MARMON - Lecturer in History, Princeton University (fall 1985-86).

DORIS S. MILlER - Assistant Director, Kevorkian Center, NYU.

Fathollah Mirza-Bagheri - Visiting Professor, Economics, University of

Pennsylvania (fall 1985).

HoSSEIN MODARRESSI - Lecturer of Islamic law and religion, Princeton U.

Clement Henry MoOre - Visiting Faculty, Political Science, UCLA.

Nidhal Shaban MOSTAFA - Professor of Education, King Saud University.

Christopher M. MURPhy - Turkish Area Specialist, Library of Congress.

BAsim MUSAllam - University Lecturer in Islamic Studies \& Senior Member,

King's College, Cambridge University.

LAURIE MYLROIE - Assistant Professor of Government, CMES, Harvard University.

AdDUllahi AHMed El NaIEM - Visiting Faculty, Law, UCLA.

MUSTAFA AL-NAJJAR - General Secretary, Union of Arab Historians, Baghdad.

AfSANEH NAJMABADI - Visiting Lecturer on Government, CMES, Harvard

University.

Vahid Nowshirvani - Adjunct Professor of Economics, Columbia University. 
WADAd AL-QADI - Visiting Professor of Arabic, Columbia University.

PATRICIA RISSO - Assistant Professor, History, Illinois State University.

JONATHAN RODGERS - Acting Secretary, American Oriental Society.

MiCHAEL ROGERS - Hagop Kevorkian Lecturship in Near Eastern Art and Civilization, NYU, March 1986.

MinNa ROSEN - Visiting Fellow, Princeton University.

HAIDEH SALEhI-ESFAhANI - Dept. of Economics, University of Utah.

Mohammed Ahmed SAlem - Professor of Civil Engineering, University of Jordan.

Elizabeth Sartain - History Dept., AUC.

Dirghām H. Sbait - Assistant Professor of Semitic Languages, Portland State University.

DANIEL SCHROETER - Department of History, University of Utah.

M. NAZIF Shahrani - Assistant Professor of Anthropology, UCLA.

ANTAR IBN-STANFORD SMITH - Chaplin, Jackson, Michigan, prison.

SASSON SOMEKH - Visiting Professor, Princeton University (spring 1985-fall $1985 / 86)$

Annabelle Sreberny-Mohammadi - Assistant Professor, Communications, Queens College, CUNY.

Fredu StAmboul - Visiting Faculty, Sociology, UCLA.

Suzanne StetKevych - Lecturer in Advanced Arabic Syntax (Fall-Winter 1985-86), University of Chicago.

SAADIA TOUVAL - Visiting Professor of Government, CMES, Harvard University.

John WATERBURY - William Steward Tod Professorship, Princeton University. BAYLY WINDER - Director, Kevorkian Center, NYU.

Ronald G. Wolfe - Vice President, Management and Computer Services, Professional Business Services, Cairo, Egypt.

JoHN E. WOODS - Director, CMES, University of Chicago.

Birol Ali Yeshilada - Visiting Assistant Professor, Political Science, Washington University, St. Louis.

\title{
Grants, Fellowships, AND AWARDS \\ AMERICAN ASSOCIATION OF UNIVERSITY WOMEN International Fellowship - 1985-1986
}

Dina Le Gall (Princeton $U$.): "The Spread of the Naqshbandiyya into the Arab Lands and Istanbul in the 17th and 18th Centuries."

\author{
HARRY S. TRUMAN RESEARCH INSTITUTE \\ FOR THE ADVANCEMENT OF PEACE \\ Nathaniel L. Goldstein Fellowship - 1982-1985
}

Alexander Bligh (Phd. 1982, Columbia University): Preparation of book Succession to the Throne in Saudi Arabia in the Twentieth Century.

HARVARD UNIVERSITY, CENTER FOR MIDDLE EASTERN STUDIES Research Appointments - 1985-1986

Ephraim Ahiram ( $T e l$ Aviv $U$.): The role of economics in the Middle East peacemaking process. 
RiAD AJAMI (Ohio State U.): Business administration, management energy and oil economics.

Selma Botman: Egyptian writer Albert Cossery.

Benjamin Braude (Boston C.): "Bedouins, Priests, and Spies: Palgrave and the Opening of Arabia," and "Textiles and Trade in the Eastern Mediterranean, 1500-1650."

William CAMPBEll (Miami U. of Ohio): Analysis of factionalization within the Islamic Republic; The emergent Franco-Saudi Arabia-Japan axis.

BeAtrice Manz (Tufts. U.): Modern history of Central Asia.

Charles Pennell ( $U$. of Singapore): History of Morocco in the second half of the seventeenth and the early eighteenth centuries.

INSTITUTE OF TURKISH STUDIES

$1985-1986$

Subventions for Publications

Tibor Halasi-Kun: Publication costs of Archivum Ottomanicum, vol. 10.

KATHLEen BURRILl: Publication costs of Turkey in America: Information and Image in the 80's.

RhoAds Murphy: Publication costs of Studies on the Ottoman Economy 1. A Sultanic Memorandum of 1636 A.D..

ŞINASI TEKIN: Partial funding for Journal of Turkish Studies, vol. 9; partial funding for Sources of Oriental Language and Literature, no. 10 "Kefe Defteri."

University of Washington Press: Towards publication of Memoir of Gian-Maria Angiolello, translated and annotated by Pierre A. MacKay.

KEMAL KARPAT: Subvention for International Journal of Turkish Studies, vol. 4 , parts $1 \& 2$.

Frank AHMED: For Anatolian Odyssey.

\section{University Library Grants for Acquisition and Cataloguing}

ARIT (upgrading); Brandeis (procurement of Turkish materials); Columbia (procurement of back numbers of Turkish serials); State University College of Arts and Science, Geneseo, NY (procurement of Turkish materials); University of Houston (procurement of Turkish materials); Hoover Institution (procurement of Turkish materials); Indiana University (procurement of Turkish materials); Pennsylvania University (procurement of Turkish materials); New York University (procurement of Turkish materials); SUNY, Binghamton (procurement of back issues of Turkish serials); University of Texas (salary for part-time cataloguing assistant); Tufts University (procurement of Turkish materials); University of Utah (procurement of Turkish materials); University of Washington (purchase of monographs published prior to 1968 and books from Ikdam and Cavaib presses); University of Wisconsin (procurement of Turkish materials.)

\section{Undergraduate Scholarships}

University of Chicago; Columbia University; Indiana University; University of Pennsylvania; University of Texas; University of Washington.

\section{Graduate Fellowships}

University of California at Berkeley; University of Chicago; Columbia University; Indiana University; University of Pennsylvania; University of Texas; University of California at Los Angeles; University of Utah; University of Washington; University of Wisconsin. 


\section{Dissertation Writing Grants}

Linda Darling ( $U$. of Chicago): Study of the organization and work of the central finance department of the Ottoman empire.

Eran Fraenkel ( $U$. of Pennsylvania): Study of the early Ottoman period in the Balkans.

Paul Gilmer ( $U$. of Texas): Study on the use of Turkish among the Jewish population of Izmir.

FATMA MUGe GoCEK (Princeton U.): Study of the rise of Western influence in the Ottoman empire in the 18th century.

Conference Travel Matching Grants

Ilhan Başgoz, Alfred Ivry, Larry Miller, Pierre Oberling.

\section{Post-Doctoral Summer Travel to Turkey}

LudWig AdAmEC: Turkish influence on modernization in Afghanistan.

ANDRAS BODROGLIGETI: Research for syllabus on course on cultural history of the Turks.

RICHARD HOFFERBERT: Consultation with Ustun Erguder on joint publication on public policy and political change in Turkey.

LT. COL. William Mitchell: Comparison study of recovery from devastation of earthquake in two localities.

DONALD QUATAERT: Effect of industrialization on handicraft in the Ottoman empire from 1750 to the beginning of World War I.

\section{Post-Doctoral Released Time}

Sarah Atş (U. of Wisconsin); Carter Findley (Ohio State U.); Paul MAGNARELLA ( $U$. of Florida).

\section{Support for Existing Programs}

University of California at Berkeley (salary for native speaker for conversational Turkish); University of Chicago (salary for native informant for class in intermediate Turkish); Columbia University (purchase of research and demonstration collection of contemporary and traditional Turkish music); University of Connecticut (general); Indiana University (general); New York University (salary for teacher of Ottoman history); University of Pennsylvania (general); Turkish Studies Association (general, especially publication of Bulletin); University of Washington (salary for teaching assistant for Turkish); Middle East Institute (purchase of films for film lending libraries.)

\section{Seed-money Grants}

University of Illinois (Turkish language course); Ohio State University (position in Turkish language and literature).

\section{Matching Funds for Conferences or Lecture Series}

University of Chicago (lecture series on Turkish art and architecture; language circles; conference on Turkish art); Columbia University (conference on rural society in Muslim Anatolia); Hunter College (conference on Turkish family and household structures); Institute of World Affairs (conference on Turkey, internal development and foreign relations); SUNY, Binghamton (seminar on the social structure of the Ottoman empire before its incorporation in the world economy); University of Texas (lecture on historic and contemporary role of Turkey in the Mideast); University of Utah (Turkish portion of public lecture series on Middle East); Tufts University (two public lectures on Turkey.) 


\section{Preparation of Teaching Aids}

Columbia University (preparation of The Columbia Encyclopedia of the Modern Middle East); Indiana University (copy and catalogue collection of Conks); KAREN MURPHY (production of videotape of karagöz plays for high school and university audiences); Turkish Studies Association (packets of materials on Turkey for grade school and high school social studies); BARBARA WALKER (production and distribution of more copies of filmstrip An American Teenager Visits Turkey).

\section{Miscellaneous Projects}

University of Chicago (continued microfiching of Ottoman materials); Summer Language Consortium (University of Pennsylvania, host this summer); STANFORD SHAW (establishment of Republic of Turkey databank at UCLA); University of Wisconsin (outreach funds for program directed at improving teaching of subjects related to Turkey at area high schools); KATHLEEN BURRILL (startup funds for American Association of Teachers of Turkish); funding for International Ottoman Studies directory, to be taken over by the Institute of Turkish Studies.

\section{Annual Award}

It was determined that the sum of $\$ 5,000$ be set aside as an endowment for an annual award for the best publication in the field in the previous 24 months, to be administered by a committee of the Turkish Studies Association.

\section{MACARTHUR FOUNDATION}

Fellowship in Arms Control, MIT - 1985-1986

PhILIP S. KhOURY (MIT).

MARSHALL G. S. HODGSON MEMORIAL PRIZE, UNIVERSITY OF CHICAGO

Best original research paper or essay on Islamic Civilization - 1984

STEVEN WASSERSTROM (Toronto University).

\section{NATIONAL ENDOWMENT FOR THE HUMANITIES \\ Translation Program Grants - 1985}

Walter R. Feldman (New York): Translation, with examples in musical notation, of the Ottoman treatise The Book of the Science of Music, by Dimitrie Cantemir.

ChARLES H. MANEKIN (Jerusalem): Completion of an annotated translation of the 14th-century work Sefer ha-Heqqesh ha-Yashar (The book of the correct syllogism), by Levi ben Gershom (Gersonides).

George A. SAliba (Columbia U.): Translation and annotation of the 13thcentury treatise Kitab al-hay'ah (Book of astronomy), by Mu'ayyad al-Din al-'Urdi.

JeAnetTe WAKIN (Columbia U.): Translation of Ibn Qudama al-Makdisi's Rawdat atnazi wa-jannat at munazir.

\section{NEW YORK UNIVERSITY \\ Fellowships - 1985-1986}

ZEINA MATAR: Lane Cooper Fellowship for research in the role of astrology in medieval Islamic society.

SARA SAYISH: CASA fellowship. 


\section{PRINCETON UNIVERSITY \\ Fellowships - 1985-1986}

Michael BonNer: Harold W. Dodds Honorific Fellowship for work on "Ideology, Religion and Social Organization in the Military Society of the Islamic Byzantine Frontier Region during the "Abbasid Era."

Michael BORNSTEIN: Lady Davis Fellowship for research on "Egypt, Israel, and the Baghdad Pact."

LOUISE MARLOW: Whiting Fellowship in the Humanities for work on "Nasir al-Din Tusi: His Political Role up to the 11th Century."

DAVID SPIRO: Harold W. Dodds Fellowship for work on "The Politics of Recycling Arab Petrodollars."

$$
\text { Visiting Fellows - 1985-1986 }
$$

ILAI ALON ( $T e l$ Aviv U.)

YESHAYAHU GOLDFELD (Bar-Ilan $U$.)

AbDerRahman El MoUdDen (Mohamed $V U$.)

Minna Rozen (Tel Aviv U.)

SOCIAL SCIENCE RESEARCH COUNCIL

Ibn Khaldun International Graduate Student Competition in Middle East Studies - 1985

Julia Clancy-Smith (UCLA): "Rebellion and Apocalypse in Colonial Algeria."

$$
\begin{gathered}
\text { SOCIAL SCIENCE RESEARCH COUNCIL OF CANADA } \\
\text { Research grant -- } 1984-1985
\end{gathered}
$$

M. H. KAMALI (International Islamic U., Selangor, Malaysia [1985]): Fundamental Rights of the Individual in Islamic Law.

WENNER-GREN FOUNDATION FOR ANTHROPOLOGICAL RESEARCH

$$
\text { Grant - 1985-1986 }
$$

Alan S. KAYE (California State, Fullerton): Juba Arabic (Sudan) and Ki-Nubi Arabic (Kenya and Uganda). 